\title{
Front Matter: Volume 11165
}

, "Front Matter: Volume 11165," Proc. SPIE 11165, Optical Materials and Biomaterials in Security and Defence Systems Technology XVI, 1116501 (5 November 2019); doi: 10.1117/12.2556643

SPIE. Event: SPIE Security + Defence, 2019, Strasbourg, France 


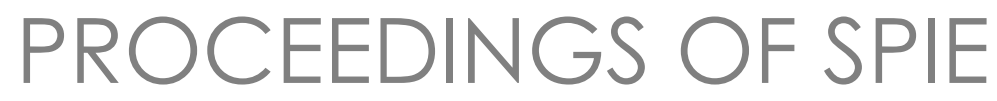

\section{Optical Materials and Biomaterials in Security and Defence Systems Technology XVI}

\section{Roberto Zamboni}

François Kajzar

Attila A. Szep

Editors

12 September 2019

Strasbourg, France

Sponsored by

SPIE

Cooperating Organisations

European Optical Society

Cranfield University (United Kingdom)

Published by

SPIE 
The papers in this volume were part of the technical conference cited on the cover and title page. Papers were selected and subject to review by the editors and conference program committee. Some conference presentations may not be available for publication. Additional papers and presentation recordings may be available online in the SPIE Digital Library at SPIEDigitalLibrary.org.

The papers reflect the work and thoughts of the authors and are published herein as submitted. The publisher is not responsible for the validity of the information or for any outcomes resulting from reliance thereon.

Please use the following format to cite material from these proceedings:

Author(s), "Title of Paper," in Optical Materials and Biomaterials in Security and Defence Systems Technology XVI, edited by Roberto Zamboni, François Kajzar, Attila A. Szep, Proceedings of SPIE Vol. 11165 (SPIE, Bellingham, WA, 2019) Seven-digit Article CID Number.

ISSN: 0277-786X

ISSN: 1996-756X (electronic)

ISBN: 9781510630338

ISBN: 9781510630345 (electronic)

Published by

SPIE

P.O. Box 10, Bellingham, Washington 98227-0010 USA

Telephone +1 3606763290 (Pacific Time) · Fax + 13606471445

SPIE.org

Copyright @ 2019, Society of Photo-Optical Instrumentation Engineers.

Copying of material in this book for internal or personal use, or for the internal or personal use of specific clients, beyond the fair use provisions granted by the U.S. Copyright Law is authorized by SPIE subject to payment of copying fees. The Transactional Reporting Service base fee for this volume is $\$ 21.00$ per article (or portion thereof), which should be paid directly to the Copyright Clearance Center (CCC), 222 Rosewood Drive, Danvers, MA 01923. Payment may also be made electronically through CCC Online at copyright.com. Other copying for republication, resale, advertising or promotion, or any form of systematic or multiple reproduction of any material in this book is prohibited except with permission in writing from the publisher. The CCC fee code is 0277$786 \times / 19 / \$ 21.00$.

Printed in the United States of America by Curran Associates, Inc., under license from SPIE.

Publication of record for individual papers is online in the SPIE Digital Library.

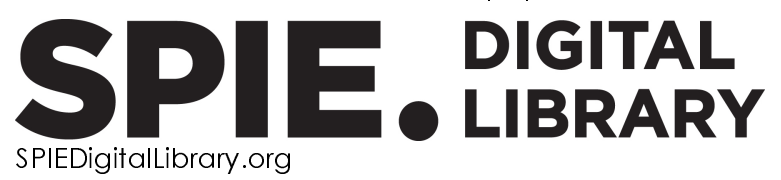

Paper Numbering: Proceedings of SPIE follow an e-First publication model. A unique citation identifier (CID) number is assigned to each article at the time of publication. Utilization of CIDs allows articles to be fully citable as soon as they are published online, and connects the same identifier to all online and print versions of the publication. SPIE uses a seven-digit CID article numbering system structured as follows:

- The first five digits correspond to the SPIE volume number.

- The last two digits indicate publication order within the volume using a Base 36 numbering system employing both numerals and letters. These two-number sets start with $00,01,02,03,04$, 05, 06, 07, 08, 09, OA, OB ... 0Z, followed by 10-1Z, 20-2Z, etc. The CID Number appears on each page of the manuscript. 


\title{
Contents
}

\author{
$\checkmark \quad$ Authors \\ vii Conference Committee
}

\section{NANOPHOTONICS}

1116505 Optical limiting properties of polymer-dye nanohybrids: a comparison between polylactide and PMMA hosts [1 $11165-4]$

LIGHT EMITTING DEVICES

$11165 \mathrm{OB} \quad$ Optical materials for printed interconnects and sensors [11165-10]

$111650 \mathrm{C} \quad \mathrm{New}$ type $\mathrm{Cu}\left(\mathrm{N}_{3}\right)_{2}$ metal-azides for laser initiation [1 $1165-11$ ] 
Proc. of SPIE Vol. $111651116501-4$

Downloaded From: https://www.spiedigitallibrary.org/conference-proceedings-of-spie on 26 Apr 2023 Terms of Use: https://www.spiedigitallibrary.org/terms-of-use 


\section{Authors}

Numbers in the index correspond to the last two digits of the seven-digit citation identifier (CID) article numbering system used in Proceedings of SPIE. The first five digits reflect the volume number. Base 36 numbering is employed for the last two digits and indicates the order of articles within the volume. Numbers start with 00, 01, 02, 03, 04, 05, 06, 07, 08, 09, OA, OB...0Z, followed by 10-1Z, 20-2Z, etc.

Aga, R. S., OB

Bartsch, C. M., OB

Dandois, M., 05

Guerchoux, M., 05

Heckman, E. M., OB

Hege, C., 05

Kreit, E. B., OB

Kuodis, Ernestas, OC

Merlat, L., 05

Muller, O., 05

Ouchen, $\mathrm{F}$., $\mathrm{OB}$

Rodin, Aleksej M., OC

Sarlauskas, Jonas, OC

Tamuliene, Jelena, $0 \mathrm{C}$

Trendel, P., 05 
Proc. of SPIE Vol. $111651116501-6$

Downloaded From: https://www.spiedigitallibrary.org/conference-proceedings-of-spie on 26 Apr 2023 Terms of Use: https://www.spiedigitallibrary.org/terms-of-use 


\title{
Conference Committee
}

\author{
Symposium Chairs
}

Ric Schleijpen, TNO (Netherlands)

Karin U. Stein, Fraunhofer-Institut für Optronik, Systemtechnik und Bildauswertung (Germany)

Symposium Co-chair

Catherine Barrat, HGH Systèmes Infrarouges (France)

Conference Chairs

Roberto Zamboni, Istituto per la Sintesi Organica e la Fotoreattività (Italy)

François Kajzar, University Politehnica of Bucharest (Romania)

Attila A. Szep, Air Force Research Laboratory (United States)

Conference Programme Committee

Chantal Andraud, Ecole Normale Supérieure de Lyon (France) André-Jean Attias, Université Pierre et Marie Curie (France)

Carrie M. Bartsch, Air Force Research Laboratory (United States)

Werner J. Blau, Trinity College Dublin (Ireland)

Fabrice Charra, Commissariat à l'Énergie Atomique (France)

Beata J. Derkowska, Torun University (Poland)

James G. Grote, Air Force Research Laboratory (United States)

Emily M. Heckman, Air Force Research Laboratory (United States)

Loïc Mager, Institut de physique et chimie des matériaux de Strasbourg (France)

Ana-Maria Manea-Saghin, University Politehnica of Bucharest (Romania)

Antoni C. Mitus, Wroclaw University of Technology (Poland)

Jaroslaw Mysliwiec, Wroclaw University of Technology (Poland)

Jacek Niziol, AGH University of Science and Technology (Poland)

Yoshiko Okada-Shudo, The University of Electro-Communications (Japan)

Fahima Ouchen, Air Force Research Laboratory (United States)

Agnieszka Pawlicka, Instituto de Química de São Carlos (Brazil)

Luana Persano, Istituto Nanoscienze (Italy)

Ullrich Pietsch, Universität Siegen (Germany)

lleana Rau, University Politehnica of Bucharest (Romania)

Ifor D. W. Samuel, University of St. Andrews (United Kingdom) 
Niyazi Serdar Sariciftci, Johannes Kepler Universität Linz (Austria)

Kenneth D. Singer, Case Western Reserve University (United States)

\section{Session Chairs}

1 Nanophotonics

Roberto Zamboni, Istituto per la Sintesi Organica e la Fotoreattività (Italy)

2 Applications

Bernard Kippelen, Georgia Institute of Technology (United States)

$3 \quad$ Light Emitting Devices

Attila Szep, Air Force Research Laboratory (United States) 